ORIGINAL ARTICLE

AFRICAN JOURNAL OF CLINICAL AND EXPERIMENTAL MICROBIOLOGY MAY $2011 \quad$ ISBN 1595-689X VOL 12 No. 2 AJCEM/200704/2801

http://www.ajol.info/journals/ajcem

COPYRIGHT 2011

AFR. J. CLN. EXPER. MICROBIOL. 12(2): 72-75

\title{
EVALUATION OF IMMUNITY AGAINST POLIOVIRUS SEROTYPES AMONG CHILDREN IN RIVERINE AREAS OF DELTA STATE, NIGERIA
}

Donbraye, E., Adewumi, M.O., Odaibo, G.N., Bakarey, A.S., Opaleye, O. O. and Olaleye, D.O.

Department of Virology, College of Medicine,

University of Ibadan, University College Hospital

Ibadan, Nigeria.

Correspondence: Professor D. O. Olaleye, Department of Virology, University College Hospital, Ibadan, Nigeria. Email: ibvirology@yahoo.com, foreodaibo@hotmail.com

\begin{abstract} were determined by the beta method of neutralization.

\section{INTRODUCTION}

In May 1988, the World Health Assembly (WHA) resolved to eradicate Poliomyelitis globally by the year 2000 (1). The global eradication of polio involves both halting the incidence of the disease and the worldwide eradication of the virus. In the African Region (AFRO) of the World Health Organization (WHO), eradication strategies were accelerated following supporting resolutions by WHO's Regional Committee for Africa in 1995 and the Organization for African Unity in 1996. Remarkable progress has been made since the initiative began in 1988 (2).
\end{abstract}

Nigeria remains one of the major reservoirs for wild poliovirus transmission despite the reported success in National Immunization Days and acute flaccid paralysis surveillance. Two hundred children aged $\leq 10$ years, were enrolled following parental consent from hard-to-reach riverine areas of Delta state of Nigeria to assess the level of protective immunity to poliovirus. Neutralizing antibodies to the three poliovirus serotypes in the serum samples of the children

Eight $(4 \%)$ of the children had no detectable antibody, $178(89 \%), 180(90 \%)$ and $181(90.5 \%)$ were positive for antibodies to poliovirus types 1,2 and 3 , respectively. Overall, $162(81 \%)$ of the children had antibodies to the three poliovirus serotypes at a titre of at least 1:8. The study shows the need for proper monitoring of vaccination coverage in such hard-to-reach riverine areas to achieve the objective of the global eradication of poliovirus.

Keywords: Neutralizing, antibody, poliovirus, serotypes, riverine, Nigeria

However, there have been reports of less-thanoptimal responses to trivalent OPV in developing countries. Patriarca et al. (3) reviewed data that accumulated in developing countries over 25 years and found 32 studies from 15 developing countries on the response of children to three doses of trivalent Sabin-derived OPV. After three doses of trivalent $\mathrm{OPV}$, there was wide variation in the proportion of children seroconverting with rates of $73 \%$ for type $1,90 \%$ for type 2 , and $70 \%$ for type 3 . Also, a large-scale randomized trial in Brazil and the Gambia has confirmed these findings. Even after eight OPV doses delivered during mass campaigns, gaps in immunity as defined by serum antibody levels, persist in some countries, especially for type 3 (4).
Although there has been improvement in the quality of surveillance for acute flaccid paralysis (AFP) and synchronized house-to-house NIDs conducted since late 2000 in Nigeria, the country still remains one of the most significant poliovirus reservoirs with 998 reported cases of acute flaccid paralysis out of which 101 were due to poliovirus infection as of early August, 2002. Consequently, children can develop poliomyelitis when infected by circulating wild polioviruses except they have sufficient levels of neutralizing antibodies against polioviruses to block the infection.

This study was therefore conducted to determine the proportion of infants with protective levels of serum neutralizing antibodies after at least two doses of OPV among children within the age at greatest risk of poliomyelitis in the riverine areas (known as hard-to-reach areas because of the difficult terrain) as a true biological marker of protection against the virus rather than using solely the vaccination coverage rate of the National Immunization Campaigns in Nigeria.

\section{MATERIALS AND METHODS}

SAMPLING METHOD

Random sampling method was used for subject selection in this study. Blood samples were collected from children aged one week to 10 years after due parental consent to participate in the study. Healthy vaccinated children were selected at random from designated health centres on 
immunization days, schools and households. Subjects selected were from the riverine communities in two local government areas of Delta state of Nigeria (5).

Bomadi and Kpakiama communities in Bomadi; and Burutu, Ogulagha and Odimodi communities in Burutu local government area of the state (Figure1).

\section{COLLECTION, TRANSPORT, PREPARATION AND STORAGE OF SAMPLES}

About $2 \mathrm{ml}$ of blood sample was collected by venepuncture from each child into a labelled sterile container free of anticoagulants or preservatives. Samples were transported to the laboratory immediately in a cold box with frozen ice packs to achieve a condition of about 4 to $8^{\circ} \mathrm{C}$. Serum samples were separated by low-speed centrifugation at $500 \mathrm{~g}$ for 5 minutes, or direct

\section{SITES AND SAMPLE SIZE}

A total of 200 blood samples were collected from children aged one week to 10 years from two local government areas in Delta state, Nigeria (Bomadi $=$ 80 , Burutu =120). The samples were collected from removal of the serum using a sterile disposable pipette after retraction of the clot. The serum was transferred to two labelled sterile cryovials per sample and stored at $-20^{\circ} \mathrm{C}$ until ready for analysis.

The samples were inactivated at $56^{\circ} \mathrm{C}$ in water bath prior to use for neutralization assay. Virus suspensions of the laboratory strain of the three poliovirus serotypes (Sabin strains) were prepared in L20B cell line. Challenge dose of $100 \mathrm{TCID}_{50}$ of poliovirus serotypes 1, 2 and 3 was determined and used for the neutralization test by the standard method of constant virus, varying serum dilutions microneutralization test as described by WHO (5).

\section{FIGURE 1: MAP OF NIGERIA SHOWING THE STATE USED FOR THE STUDY}

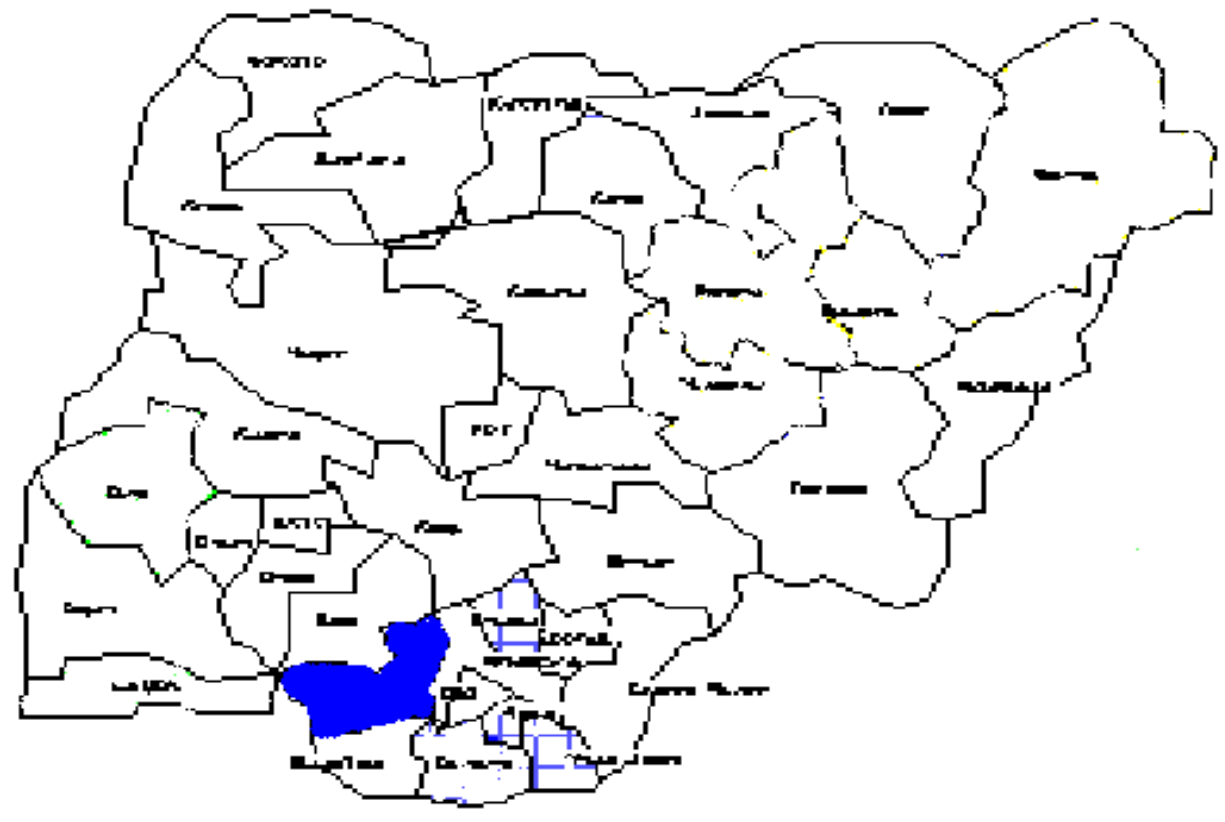

Delta State 


\section{RESULTS}

All serum samples were collected from children 10 years of age and below. There were 97 males and 103 females. Overall, 178 (89\%), 180 (90\%) and 181 $(90.5 \%)$ of the 200 blood samples tested had antibody titres of 8 or higher against poliovirus types 1, 2 and 3, respectively (Table 1). Also, 167 $(83.5 \%), 160(80 \%)$ and $158(79 \%)$ had antibody titres of 32 or higher against poliovirus types 1,2 and 3, respectively (Table 1). Moreover, 162 (81\%) had antibody titres of 8 or higher against all three polioviruses, while $8(4 \%)$ were completely seronegative to the three poliovirus serotypes, 2 (1\%) had antibody titre of 8 or higher against P1 only, $2(1 \%)$ had antibody titre of 8 or higher against P2 only and $1(0.5 \%)$ had antibody titre of 8 against P3 only. The parents claimed to have received two or more doses of OPV for their children.

\section{TABLE 1: NEUTRALIZING ANTIBODIES} TO POLIOVIRUS SEROTYPES

\begin{tabular}{|c|c|c|c|}
\hline $\begin{array}{l}\text { ANTI } \\
\text { BODY }\end{array}$ & P1 & P2 & P3 \\
\hline TITRE & NO. ( $(\%)$ & NO. ( $(\%)$ & NO. ( (\%) \\
\hline$\geq 8$ & $178(89.0)$ & $180(90.0)$ & $181(90.5)$ \\
\hline$\geq 32$ & $167(83.5)$ & $160(80.0)$ & $158(79.0)$ \\
\hline
\end{tabular}

For the male children, 81 (83.5\%), $82(84.5 \%)$ and 83 $(85.6 \%)$ had antibody titres of 8 or higher against poliovirus types 1, 2 and 3 respectively. However, among the female children, 97 (94.2\%), 98 (95.1\%) and $98(95.1 \%)$ had antibody titres of 8 or higher against poliovirus types 1,2 and 3 respectively (Figure 2).

\section{DISCUSSION}

Tests for serum neutralizing antibodies are considered to be the most specific for evaluation of the protective antibody response to poliovirus infections. Persons are presumed to be protected against disease caused by a particular type of poliovirus if they develop type-specific serum neutralizing antibodies to the virus. Antibody surveys are a more reliable method of assessing immunity than either statistics of vaccine uptake (or coverage) or sporadic cases or outbreaks of paralytic poliomyelitis which signals a dangerous decline of immunity due to complacent under vaccination or to technical flaws in the vaccination procedure.

This study showed the presence of neutralizing antibodies against poliovirus types 1,2 and 3 in children from five riverine communities in two local government areas of Delta state, Nigeria. After claims to have received at least two doses of oral polio vaccine (OPV), by their parents, there was variation in the percentage of children seroconverting. Overall, $89 \%, 90 \%$ and $90.5 \%$ had antibody titre of 8 or higher against poliovirus types 1,2 and 3, respectively. These results agree with reports from other countries where there have also been less than optimal responses to trivalent OPV $(3,6)$.

Eighty-one percent (81\%) of the children had antibody to poliovirus types 1,2 and 3 at a titre of 8 or higher. These leave non-immunized pockets of children who were seronegative to one or more poliovirus types. These non-immunized children, as against NPI reports of $108 \%$ immunization coverage in the second round of the 1999 NIDs, favour continued spread and outbreaks of poliovirus infection $(2,7)$. These gaps in immunity levels raise concerns of either primary vaccine failure, that is, lack of initial antibody responses where potent vaccines are used or, failure of the cold chain and the subsequent use of non-potent vaccines in the field.

Furthermore, the children had $83.5 \%, 80 \%$ and $70 \%$ seropositivity for poliovirus types 1, 2 and 3 , respectively, for neutralizing antibody titre of 32 or above. Although the level of serum neutralizing antibody which protects against clinical illness has not been determined, studies have indicated that persons with low serum neutralizing antibody titre post immunization can be reinfected by wild virus or when challenged with vaccine virus $(8,9,10)$. In animal experiments, passively administered antibody that provides moderate serum antibody levels (titre of 20 or higher) is likely to protect against clinical illness, but this cannot be compared with the natural situation where challenge with wild or vaccine strains occurs (11). These studies suggest that persons with low but detectable serum antibody levels are probably not in danger of developing clinical poliomyelitis. However, they may be reinfected with poliovirus and possibly become a source of infection for others who have not been vaccinated or have been vaccinated but seronegative.

In addition, it was observed that a higher percentage of the female children, compared to the males, were seropositive to poliovirus types 1,2 and 3 . On the other hand it was also noticed that seropositivity for neutralizing antibodies against poliovirus types 1,2 and 3 is not age dependent. Seropositivity did not decrease with increasing age of children. This can be explained to be a consequence of antibody boosting resulting from continuous exposure to the virus in an endemic area (9).

The areas where the samples were collected from Delta state (Bomadi and Burutu) of Nigeria are riverine often described as hard-to-reach. In these 
areas, households are crowded and mostly with poor hygiene. Members of a household defecate; take their baths, swim and sometime drink from the same water source (streams and rivers). Faeces of infected children serve as source of contamination of water and virus dissemination is facilitated by poor sanitation and overcrowding. Ashley et al. (12), in a survey in Jamaica obtained sera from more than 2500 children and adolescents in a population based study involving children aged up to 19 years and showed that among children 1-4 years that had never received vaccine $53 \%, 77 \%$ and $55 \%$ were seropositive for $\mathrm{P} 1, \mathrm{P} 2$ and $\mathrm{P} 3$ respectively, probably reflecting circulation of both wild and secondary vaccine virus. Circulation of poliovirus due to poor sanitation and existence of unhygienic environment conditions could be contributing factors to the spread of the virus (13).

\section{CONCLUSION}

The present study demonstrates $81 \%$ herd immunity for the three-poliovirus serotypes among children in five riverine communities in two local government areas of Delta state of Nigeria. Identification of some children without detectable antibodies to one or more poliovirus serotypes, in their sera, show that pockets of susceptible individuals are still present within the population.

\section{REFERENCES}

1. World Health Organization. Global Eradication of poliomyelitis by the year 2000 (Resolution WHA 41.28): resolution of the 41st World Health Assembly 1988 Geneva, Switzerland.

2. World Health Organization. Global status of polio eradication initiative in: Background on Polio eradication 2000; 1 of 2.

3. Patriarca PA, Wright PS, John TJ. Factors affecting the immunogenicity of oral polio vaccine in developing countries: a review Rev Int. Dis 1991; 13: 926-939.

4. World Health Organization. Immunological basis for immunization series, Module 6: Poliomyelitis 1993; 24PP. WHO/EPI/GEN/93.16 (document).

5. World Health Organization. Manual for the Virology investigation of Polio 1997; 66PP. WHO/EPI/GEN/97.01.EPI:

6. Expanded Programme on Immunization. Rapid assessment of serological response to oral polio vaccine - Pakistan, Togo, Uganda. Wkly Epidemiol. Rec. 1990; 65: 34-35.

7. National Programme on Immunization. Reports on National immunization Days (Houseto-House Strategy): October-November, 1999.

8. Gelfand HM, LeBlanc Dr., Potash L, Fox JP. Studies on the development of natural
Such individuals favour the continued spread and circulation of the virus in the population. Therefore, increased vaccination coverage as a result of more frequent NIDs, and increased coverage by routine immunization in Nigeria, may reduce the number of such children and go a long way to ensure the eventual elimination of poliomyelitis and wild poliovirus from the country.

There is the need to re-evaluate the vaccination programmes and implementation of the global polio eradication policy in Nigeria to improve effectiveness and eventual eradication of polio from the country. Also there is the need for monitoring of the various stages of the programme and include vaccine potency testing and protective polio antibody testing to assess the level of immunity to poliovirus serotypes among children at risk of the virus infection.

\section{ACKNOWLEDGEMENTS}

Our profound gratitude goes to the entire children population who participated in the study and their parents for their cooperation. The financial support for this study was provided through the University of Ibadan Senate Research to DOO of the Department of Virology, University College Hospital, Ibadan.

immunity to poliomyelitis in Louisiana IV Natural infections with polioviruses following immunization with a formalin-inactivated vaccine Amer. J Hyg. 1959; 70: 312-327.

9. Nishio O, Ishihara $\mathrm{Y}$, Sakae $\mathrm{K}$, Nomomura $\mathrm{Y}$, Kuno A, Yasukawa S, Inoue $\mathrm{H}$, Miyamura K, Kono R. The trend of acquired immunity with live poliovirus vaccine and the effect of revaccination: follow-up of vaccinees for ten years J Biol Stand 1984; 12:1-10.

10. Magrath D, Bainton D, Freeman M. Response of children to a single dose of oral or inactivated polio vaccine Dev Biol Stand 1981; 47: 223-226.

11. Bodian D and Nathanson N. Inhibitory effects of passive antibody on virulent poliovirus excretion and on immune response of chimpanzees. Bull Johns Hopkins Hospital 1960; 107: 143-162.

12. Ashley D, Fox K, Figueroa JP, Hull B. Polio immunization and serological status in children and adolescents in Jamaica. WI Med. J. 1989; 38: 23-29.

13. Adu FD, Odemuyiwa SO, Tomori O. Circulation of poliovirus among risk group in Ibadan. Nigeria. Transaction of the Royal society of the Tropic Medicine and Hygiene 1996; 90: 126-127 